\title{
Production and marketing management of organic and inorganic dry chilli in Dharwad district
}

\author{
P.M. SHRUTI AND C. MURTHY
}

Received : 21.07.2017; Revised : 06.09.2017; Accepted : 20.09.2017

\begin{abstract}
The present study was conducted in Dharwad district, the major dry chilli producing district of north Karnataka. For the study, 10 organic farmers and 50 inorganic farmers were selected randomly in the study area. The estimated per hectare cost of cultivation of organic and inorganic dry chilli was Rs. 50,342.61 and Rs. 56,337.72, respectively. Average yield of organic chilli was 6.87 tonnes as against 10.75 tonnes in inorganic dry chilli per hectare. The per quintal of dry chilli prices in organic and inorganic were Rs. 19,565 and Rs. 15,150 , respectively. The gross returns of inorganic dry chilli were Rs. 1,62,862.50 per hectare as against Rs. 1,34,411.55 for organic dry chilli. The net returns of inorganic dry chilli (Rs. 1,07,524.78) were higher than that of organic dry chilli (Rs. 84,068.94). The B: C ratio for inorganic dry chilli was 1.90 as against 1.85 for organic dry chilli. It was observed that only two marketing channels were using, channel-I was more marketing efficiency compared to channelII. Most of the farmers were using channel-I.

KEY WORDS : Cost and returns of organic, Inorganic dry chilli, Price spread, Channels, Cultivation of chilli, Marketing efficiency

How to cite this paper : Shruti, P.M. and Murthy, C. (2017). Production and marketing management of organic and inorganic dry chilli in Dharwad district. Internat. J. Com. \& Bus. Manage, 10(2) : 198-204, DOI: 10.15740/HAS/IJCBM/10.2/198-204.
\end{abstract}

\section{MEMBERS OF THE RESEARCH FORUM}

Correspondence to:

C. MURTHY, Department of Agribusiness Management, College of Agriculture, University of Agricultural Sciences, DHARWAD (KARNATAKA) INDIA

Email: cmurthy1966@gmail.com

\section{Authors' affiliations:}

P.M. SHRUTI, Department of Agribusiness Management, College of Agriculture, University of Agricultural Sciences, DHARWAD (KARNATAKA) INDIA 